Article

\title{
Plenty of Fish in the Academy: On Marshall McLuhan's Prose as an Anti-Environment
}

\author{
Kate Gromova \\ Book and Media Studies, University of St. Michael's College in the University of Toronto, 81 St. Mary St, \\ Toronto, ON M5S 1J4, Canada; kate.gromova@mail.utoronto.ca \\ Academic Editor: Robert K. Logan \\ Received: 12 November 2016; Accepted: 3 March 2017; Published: 23 March 2017
}

\begin{abstract}
The purpose of this synthesis is to deconstruct the medium of Marshall McLuhan's prose as an anti-environment for the medium of traditional academic writing. By placing McLuhan's own theory in dialogue with the founding principles of linguistic anthropology, I will argue that McLuhan's authorial tactics-a subject of his long-term repudiation by the academic community on the whole-adhered to the tenets of the Electric Age, and were thus inherently incomprehensible to those who negotiated academic prose as a medium locked within the media environment of the Print Age.
\end{abstract}

Keywords: McLuhan; media ecology; prose; figure and ground; the medium is the message; linguistic anthropology

\section{Introduction}

"One thing about which fish know exactly nothing is water, since they have no anti-environment which would enable them to perceive the element they live in."-Marshall McLuhan, War and Peace in the Global Village [1].

For decades, the opponents of Marshall McLuhan have almost unanimously focused their criticisms on the non-conformative style of his prose. McLuhan's writing has been described as impervious, veiled, arcane, non-academic, and at times-unacceptable. Led by his contemporaries from all paths of the Academy-including a plethora of canonical scholars such as Dwight MacDonald and Umberto Eco- the attack on McLuhan's authorial technique has grown so pervasive that David Carr, somewhat jokingly, noted the existence of an entire line of "academics who have made a career out of deconstructing McLuhan's effort to define the modern media ecosystem" [2].

And yet, a study of McLuhan's prose under the lens of his own theory, reveals a complex and by no means arbitrary motivation behind McLuhan's rebellion against the tenets of traditional academic writing. The purpose of this essay is to uncover the structure and function of this rebellion-which, I believe, are grounded in McLuhan's determination to create a linguistic medium that adheres to and reflects the environment of the Electric Age, as opposed to the one of the Print Age.

The first part of this essay will intersect McLuhan's views on media ecology with the methodological apparatus of linguistic anthropology in order to articulate the specificity of prose as a medium. In the second part of my synthesis, I will deconstruct the idea of linearity as a direct outcome and a requirement of the Print Age; and contrast it to the non-linear and acoustic composition of McLuhan's writing that exists within the environment of the Electric (and now-Digital) Ages. Finally, I will examine the criticisms of McLuhan's authorial tactics from the standpoint of what he refers to as the Age of Anxiety. 


\section{The Medium is the Prose}

In order to delve into the medium-specificity of McLuhan's literary devices, we must first arrive at a sound understanding of how the linguistic components of prose itself function as a medium. Ferdinand de Saussure distinguishes between the two fundamentals of codified language: langue and parole. He defines the former as an abstract system of signs that pre-exists its users and the very act of speech itself. In other words, langue is a set of rules and practical conventions that govern transitions of meaning (e.g., phonetics, grammar, and punctuation). The latter, parole, refers to the concrete instances of langue and its use in individual acts of communication, such as all forms of actual writing and speech (de Saussure, 1959 [3] (pp. 9-10, 15)).

In Understanding Media, McLuhan insists that "the content of each medium is always another medium (McLuhan, 1994 [4] (p. 8))." Academic writing is thus a medium of written parole-which is, in its own turn, a medium of English langue. As such, academic parole is, by definition, an entity both distinct from its counterparts (e.g., a vernacular conversation and writing) and dependent on the conventions of langue as its encompassing medium (e.g., academic prose and a vernacular conversation share the basic grammatical structure of langue). It is pivotal that langue and parole are neither autonomous nor innately chronological: the very structure of langue cannot be revealed other than through parole, while parole cannot take place without langue (de Saussure, 1959 [3] (p. 97)). Furthermore, a considerable shift in parole (such as the birth of a dialect in the process of colonization, or the introduction of a new cultural vocabulary) ultimately leads to a change in langue. This relationship articulates the guiding tenet of linguistic anthropology: a view that language, thought, and culture are intertwined and depend on one another in their change and development (Danesi, 2008 [5] (pp. 19-20, 29-30)). Thus, in McLuhan's terms, parole is the figure and langue is the ground in which the figure of parole operates.

This notion of such interconnectivity is almost directly echoed in McLuhan's own theory, as he suggests that no given medium exists in isolation, but rather participates in what McLuhan refers to as media ecology. Simply put, media-much like languages and biological species-exist in constant interaction with one another and their ever changing environments, as they "struggle through various mutations in a desperate attempt at adaptation and survival" (Logan, 2013 [6] (p. 89)). It is important to note that the very term "environment", in the case of language as a medium, can be explored in at least four principal ways; and the development of English language bears witness to such a heterogeneity. First, media environment of any given language can be studied as a totality of interactions between its own medium and the media of other codified languages. Second, it can be negotiated in terms of its interaction with the macro-medium of a social institution. Third, it can be discussed as a denotative biological environment. Finally, it can be conceived of as the media age (e.g., the age of orality as opposed to literacy, or the electric and digital ages). Consider the early stage of English language:

In the year $43 \mathrm{AD}$, King Gwydr of Catuvellauni refused to pay tribute to Rome. Enraged, Emperor Claudius responded by leading his armies to Kent (Latin-speaking troops thus introduced the medium of a new codified language into an environment previously dominated by Celtic langue and parole). Celtic rulers united to march against the invaders, but their troops were greatly outnumbered. King Gwydr was slayed in the battle and his allies were forced to surrender. Thus begun the Roman colonization of Britain (no longer the dominant language, Pictish faced further amalgamation with Latin, as a new social order solidified). As Latin engulfed the Island, Pictish remained untouched only far into the North, where the landscape of Highlands (geological medium as an environment of its own) protected them from the invasion for some three hundred years after. Celtic langue thus became the linguistic system of a minority, eventually extending and solidifying into a symbol of anti-colonialism at the rise of the electric age.

McLuhan expands on the nature of change in terms of what he refers to as figure and groundan apparent and tangible medium and the mostly imperceptible domain in which it takes place. Change, according to McLuhan, occurs in the ground much earlier than it does in the figure, and the only way of conceptualizing the effects of any given figure is to observe it against a new ground. 
This becomes possible in the emergence of a new environment (or an anti-environment), which is the ground of a new medium that, according to McLuhan, strips the cloak of invisibility from the existent environment (Logan, 2013 [6] (pp. 29-30, 34)). The multiplicity of phenomena that served the function of a ground to the figure of early English language, in this way, concludes another critical point of interaction between McLuhan's theory and the field of linguistic anthropology: parole as a figure can be studied against a multitude of grounds. As such, the meanings and effects of academic writing, too, vary in their relationship to different media ecologies.

McLuhan's notion of a medium as the content of another medium, combined with the Saussurian definition of linguistic categories, allows us to unpack the idea of language in so far as to suggest that the very notion of an authorial tactic is in itself parole. Thus, the conflict between McLuhan's writing and what is widely perceived as the academic language proper is, in its root, a conflict between the two extensions of the same codified language. I will return to the question of this confrontation later, when we consider the functionality of each medium within the Age of Anxiety, but first-we must lay the ground for such an analysis by revealing the very framework of differences that constitute a void between the two forms of writing.

\section{The "Proper" and the Postmodern}

The looming dissimilarity between traditional academic prose and McLuhan's writing is that they are precisely antipodean in their relationship to linearity: where the former insists on chronology, the latter is simultaneous; where the former provides explanation, the latter demands interpretation; where the former adheres to the constructs of modernism, the latter embodies a postmodern pastiche. It is hardly accidental that combined, these differences constitute the very dichotomy of the Print and Electric (now-Digital) Ages. Thus, the effects of each parole must be studied according to their respective allegiance.

Unlike a literary text that provides the author with agency over the composition and progression of the narrative, traditional academic writing is highly formulaic. It does not simply insist on, but rather arises, from linearity. It demands that a thesis precedes a synthesis, and that the arguments within the latter develop in either chronological or teleological manner. A standpoint in traditional academic writing is seen predominantly as a process that necessitates a clear introduction, a methodologically-specified development, and a steady conclusion. The "gaps" in the flow of academic narratives are generally conceived of as a failure to consider the adjacent phenomena; unless, of course, they are introduced as forthcoming research questions. The insistence on such linearity derives, in part, from the idea that academic writing is but a mean of communication - a way of transmitting the required information without considering the implications of the written form as a medium.

The structures of McLuhan writing defy all of these criteria. McLuhan rejects the mandate of introduction, often beginning his chapters by delving straight into the synthesis (such as in case of his deconstruction of King Lear's narrative at the beginning of the Gutenberg Galaxy). In Medium is the Massage [7], he avoids the bounds of thesis-based hierarchy altogether by shaping his concepts into series of independent micro-syntheses, as opposed to a collection of chronological arguments that lead to a singular shared conclusion. He is in habit of returning to the topics he had previously explored and continuing his synthesis further (again, the case study of King Lear develops through several sections of Gutenberg Galaxy). And finally, he by all means rejects the final commandment of the academic style proper by introducing new arguments and open-ended statements in what is supposed to be a closing paragraph (e.g., "Panic about automation as a threat of uniformity on a world scale is the projection into the future of mechanical standardization and specialism, which are now past." in the closing line of Understanding Media).

For McLuhan, linearity is a global-scale consequence of the printed medium itself. It is a way of being that consumes the entirety of a culture, as opposed to a mere mode of communicating a thought. For him, it is precisely the linearity of a printed page that leads to the cognitive linearity of mind-a process that, according to McLuhan, ends in the culture of nominalism (McLuhan, 
1962 [8] (pp. 81-83)). If the collective mind-space of an oral culture exists in what McLuhan refers to as an open system - or a way of being in which humans experience the entirety of their sensory perceptions, and thus meanings, in a state of equilibrium - then the mind-space of a "typographic men" exists in a closed system dominated by the sense of sight (McLuhan, 1962 [8] (p. 39)). As a result, a member of the oral culture is capable of perceiving a multitude of concurrent phenomena simultaneously, while a member of the literate society invariably seeks chronological representation. The easiest way to explain this reference is to draw from the basic divide of geometries: if the mental space of an oral culture unfolds itself as the curved Riemannian Spacetime, the mind of a "typographic man" operates within the margins of a Euclidian plane. The "typographic man" within the medium of traditional academic writing thus perceives the synergy of simultaneous qualities as a chronological progression of singular events. (McLuhan, 1962 [8] (p. 82)). And yet, a new medium, according to McLuhan, both changes the existent media ecology and retrieves an older form from the past (Logan, 2013 [6] (p. 97)). McLuhan himself declares that the "Gutenberg Galaxy", as the realm of the typographic culture, "was theoretically dissolved in 1905 with the discovery of curved space, but in practice it had been invaded by the telegraph two generations before that" (McLuhan, 1962 [8] (p. 286)). The media of the electric, and now digital, age retrieve the acoustic space of the orality, thus defying linearity and demanding interaction with all sensory senses, as opposed to just sight (McLuhan, 1962 [8] (p. 286)). Hence, McLuhan's own insistence on non-linear communication of thought is by no means a failure of clarity, but rather a statement of allegiance to a new media environment.

The non-linear nature of McLuhan's prose does not end in the structure of his work-it extends into the very mode of his authorial presence. Two of McLuhan's signature techniques-idiosyncratic writing and probe-are crucial in this regard. As we previously discussed, the function of traditional academic prose is to communicate solidified meaning. In other words, it is, in the first place, explanatory. McLuhan's writing, on the other hand, resists immediate explanation. Instead, it reveals meaning through series of connections between pre-existing works without necessarily providing a denotation of ways in which they are interconnected (his way of correlating the works of Blake with Ruskin's criticism of the grotesque in the Gutenberg Galaxy is perhaps the most vivid example of this). Instead of being provided with an unambiguous statement the way readers of traditional academic writing are supplied with theses, McLuhan's readers are forced to engage their critical faculties in order the decipher, as opposed to consume, meaning. Elena Lamberti effectively coins this literary device as "McLuhan's mosaic", alluding to its striking similarity to the postmodern pastiche (McLuhan, 1962 [8] (p. xxix)).

Since the readers of McLuhan are not provided with a direct pathway from one reference to another, they must negotiate it based on their own interpretation of each source and establish a framework of narrative similarities that will invariably change based on the unique background of each reader. Simply put, if the parole of academic writing proper attends to the tenets of modernist singularity, McLuhan leans towards a hermeneutical construct of authorship in the postmodern age. In a sense, McLuhan's writing epitomizes Roland Barthes' declaration of authorial death-an idea that it is the reader, as opposed to the writer, that takes control over the production of meaning; or, as McLuhan himself put it, "the user is the content" [9].

We may thus conclude that both the structure and mode of McLuhan's writing adhere to the non-linear and simultaneous parole of the electric age. The nature of McLuhan's probes, however, presents a far more intricate case, as they delve into the very nature of langue. Linguistically, McLuhan's probe can be summarized as a metonymy - a sign that seeks to represent the totality of an entity through a quality of its segment (for instance, the term "white collar" derives from a feature most commonly associated with the apparel of office workers). But as we previously established, McLuhan is not interested in the direct transition of information-he seeks to engage the reader in the act of producing the meaning. Consider, for instance, the probe McLuhan famously used in his interview with Playboy: "The content or message of any particular medium has about as much importance as the stencilling on the casting of an atomic bomb" [10]. McLuhan's statement is distinctly metonymic, as it seeks to communicate the concept of medium as the message through its symbolic representation. By the time 
the interview took place in 1969, the image of a nuclear bomb (the medium) was firmly carved in the cultural imagination of most North Americans due to the fear of a nuclear strike. The visual of the stencil on the shell of a nuclear bomb, however, is far less prolific. Unlike the image of a white collar that evokes immediate understanding in the mind of reader, the image of a stencil requires further deconstruction: a reader must visualize the casting of a bomb and conclude that the stencil is marginal to the effects of a nuclear explosion in the same way that the textual message is marginal to the effects of a medium that contains it. In other words, the reader must perform an act of critical thinking, as opposed to an act of receiving information. In doing so, they dissolve the linearity of metonymy within langue-as it now functions not simply as a mean of evoking a mental image, but as a way of constructing meaning.

\section{The Age of Anxiety}

In conclusion, the specificity of McLuhan's prose as a medium can be summarized in accordance with his very own Laws of Media: (1) His writing enhances the faculty of critical thinking; (2) In doing so, it obsoletes linearity of the printed medium; (3) It retrieves the acoustic space of the Oral Age; (4) And it flips into academic postmodernism: a paradigm of intellectual production that stems from hermeneutics - as opposed to objectivism, intertextuality-as opposed to a restriction to singular disciplines, and simultaneity-as opposed to linearity of its form.

Now that we have uncovered the structure and function of McLuhan's literary approach, we can use it to consider the very nature of the antagonisms it endured within the institution of traditional academe. Two key aspects of McLuhan's theory will aid in this undertaking. First, the idea that the effects of any given medium become apparent only in the context of a new ground, a statement allegorized in one of McLuhan's most cited probes-"one thing about which fish know exactly nothing is water". Unsurprisingly, this notion is by no means absent from the field of linguistic anthropology. In Les Tristes Tropiques [11], for instance, Claude Lévi-Strauss famously laments his encounter with a community, previously unfamiliar with the written medium. In his attempts to impose literacy upon an oral society, Lévi-Strauss discovers that its chiefs effectively appropriate the written word as way of enhancing their agency within the group, as opposed to a mean of communicating their messages. As McLuhan will explain years later, new media do not simply replace, but rather "complicate" one another and their environments (McLuhan, 1962 [8] (pp. xli, 47)). Displaced within the oral environment, and much to the dismay of Lévi-Strauss, the typographic medium simply extended into a different set of effects. Not unlike it, the inherently electric medium of McLuhan's writing is perceived in a far different light by the academic culture of the Print Age. The overwhelmingly negative response to McLuhan's prose, from this perspective, is by no means different from Lévi-Strauss frustration at the chief who simply amalgamated a new medium into the environment of his own culture. In Medium is the Massage, McLuhan himself refers to this phenomenon as the Age of Anxiety-a turbulent transition between changing media ecologies, which he believes to be "the result of trying to do today's job with yesterday's tools" (McLuhan, 2001 [7] (p.10)).

Conflicts of Interest: The author declares no conflict of interest.

\section{References}

1. McLuhan, M.; Fiore, Q. War and Peace in the Global Village; Ginko Press: Berkeley, CA, USA, 2001.

2. Carr, D. McLuhan: Media Savant. The New York Times, 6 January 2011.

3. De Saussure, F. Course in General Linguistics; Philosophical Library: New York, NY, USA, 1959.

4. McLuhan, M. Understanding Media: The Extensions of Man; MIT: Cambridge, MA, USA, 1994.

5. Danesi, M. Language, Society, and Culture: Introducing Anthropological Linguistics; Routledge: Abingdon-on-Thames, UK, 2008.

6. Logan, R. McLuhan Misunderstood: Setting the Record Straight; Key Publishing House: Toronto, ON, Canada, 2013.

7. McLuhan, M.; Fiore, Q.; Agel, J. The Medium Is the Massage; Ginko Press: Berkeley, CA, USA, 2001. 
8. McLuhan, M. Gutenberg Galaxy: The Making of Typographic Man; University of Toronto Press: Toronto, ON, Canada, 1962.

9. Tomorrow Show with Tom Snyder, 6 September 1976; NBC: New York, NY, USA, 1976.

10. McLuhan, M. Playboy Magazine Interview; Playboy Magazine: New York, NY, USA, 1969.

11. Lévi-Strauss, Ce. Les Tristes Tropiques; Atheneum: New York, NY, USA, 1974. 